\title{
Meneladani KH. Ahmad Dahlan
}

\author{
Fathurozi \\ Staf Balai Penelitian dan Pengembangan Agama Semarang
}

KH. Ahmad Dahlan, pendiri Muhammadiyah pada 1912 pernah memberikan wejangan kepada warganya "Jangan mencari hidup di Muhammadiyah, tapi hidupkanlah Muhammadiyah." Pesannya simpel, namun mendalam. Kyai Dahlan, dalam wasiatnya, menekankan pentingnya keikhlasan dan ketulusan dalam memperjuangkan agama. Justru di sanalah spirit kehidupan ormas Islam dengan lembaga pendidikan paling banyak di dunia ini menemukan relevansinya.

Muktamar seabad Muhammadiyah 3-8 Juli 2010 di Yogyakarta bergema begitu marak. Tentu kita tidak mengharapkan kemeriahan acaranya saja. Ada yang lebih penting dari acara-acara seremonial lainnya, yakni penguatan kekuatan politik sipil dan sosial keagamaan.

Muhammadiyah punya modal sosial dan ekonomi yang begitu besar. Kalau bisa dimanfaatkan dengan baik, hal itu akan berdampak secara positif terhadap pengembangan sumber daya manusia. Lahan garap Muhammadiyah memang di sini, karena ia adalah organisasi sosial keagamaan yang memiliki misi dakwah sosial amar ma'ruf nahi mungkar.

Sepatutnyalah Muhammadiyah menjadi kekuatan yang secara aktif memberikan sumbangsih mencerdaskan kehidupan bangsa dengan ribuan lembaga pendidikan yang dimiliki serta memberikan jaminan kesehatan masyarakat dengan ribuan rumah sakit yang didirikan.

Khittah 1912 Muhammadiyah sebagai ormas besar yang memiliki peranan penting dalam kehidupan berbangsa dan bernegara akan tetap lestari bila tetap konsisten menjaga jarak terhadap kekuasaan seperti di era kepemimpinan KH. Abdul Razak Fachrudin (1968-1990). Pilihan dakwah di luar jalur politik praktis inilah yang membuat Muhammadiyah mencapai satu usia satu abad dengan prestasi gemilang dalam bidang ketahanan sosial, sebuah usia senja yang memberikan harapan emas masa depan.

Ketahanan Muhammadiyah terletak pada konsistensi dakwah sosialnya, bukan pada politik praktis. Selama ini, tarikan Muhammadiyah untuk masuk secara tidak langsung dalam dunia politik keperataian memang sungguh besar, mengingat jumlah anggotanya di tanah air mencapai 30 juta jiwa. Kalkulasi politik siapapun akan menempatkan Muhammadiyah sebagai ormas yang bisa dijadikan basis kekuatan politik akar rumput.

Modal sosial dengan jumlah massa yang begitu banyak harus dikelola dengan kepemimpinan sosial yang konsisten terhadap misi dakwah sosial dan tetap merakyat. Saya termasuk orang paling kagum kepada Pak AR (panggilan akrab KH. Abdul Razak), pemipin 
Muhammadiyah selama 22 tahun. Dia adalah sosok pemimpin yang tegas, amanah, tapi tetap sederhana dan njawani.

Untuk memenuhi kebutuhan hidup, beliau berjualan bensin eceran di depan rumahnya, jalan Cik Di Tiro, Yogyakarta. Presiden Soeharto berkali-kelai menawarkan rumah, tapi ditolak. Begitu pula, saat ditawari posisi menteri, Pak AR menolak secara halus dengan mengatakan "Kulo mboten pantes dados menteri/ saya tidak pantas jadi menteri." Meskipun sederhana, Pak AR tetap dihormati oleh kalangan masyarakat dari berbagai lapisan.

Usia emas satu abad Muhammadiyah adalah momentum mengharapkan kembali sosok pemimpin yang tidak mencari hidup, tapi justru yang menghidupkan Muhammadiyah seperti Pak AR tadi. 